\title{
HOMO EUDAIMONICUS: A ROLE OF A NEW ANTHROPOLOGICAL MODEL IN REFORMATTING A CONTEMPORARY SYSTEM OF EDUCATION
}

In Happiness And Contemporary Society : Conference Proceedings Volume (Lviv, March, 20-21, 2021). Lviv: SPOLOM, 2021. P. 171-174. https://doi.org/10.31108/7.2021.39

ISBN 978-966-919-697-2

НОМO EUDAIMONICUS: РОЛЬ НОВӦ̈ АНТРОПОЛОГІЧНОЇ МОДЕЛІ У ПЕРЕФОРМАТУВАННІ СУЧАСНОЇ СИСТЕМИ ОСВІТИ

// Щастя та сучасне суспільство : збірник матеріалів міжнародної наукової конференції (Львів, 20-21 березня 2021 р.). - Львів : СПОЛОМ, 2021. С. 171-174. https://doi.org/10.31108/7.2021.39

ISBN 978-966-919-697-2 
https://doi.org/10.31108/7.2021.39

\title{
LUSHCH-PURII Uliana
}

PhD in Philosophy, Associate Professor

Co-founder and Coordinator of International Cooperation

of the Ukrainian Institute for Happiness Research

Associate Professor at Danylo Halytsky Lviv National Medical University

(Lviv, Ukraine)

\section{HOMO EUDAIMONICUS: \\ A ROLE OF A NEW ANTHROPOLOGICAL MODEL IN REFORMATTING A CONTEMPORARY SYSTEM OF EDUCATION}

Peculiarities of a new anthropological model homo eudaimonicus are analysed, as well as the specificity and perspectives of its implementation in the contemporary system of education. The efficiency of homo eudaimonicus model for the achievement of sustainable and lasting happiness, increase of life satisfaction level and enhancement of environmental behavior of a person is elucidated. It is explicated that the purpose of happiness-oriented education is to teach children ways of achieving happiness from socially useful activities. Methodsand techniques for mastering the temporal continuum of happiness are suggested, that is to experience happiness due to happy memories, appreciation of the present and positive scenarios of the future.

Keywords: homo eudaimonicus, happiness, happiness-oriented education, social business, environmental awareness.

\author{
ЛУЩ-ПУРІЙ Уляна \\ кандидат філософських наук, дочент, \\ співзасновниия та координаторка міжнародної співпрачиі \\ Украӥнського інституту дослідження щастя, \\ Доцент Львівського національного медичного університету імені Данила \\ Галичького (Львів, Укріїна)
}

\section{НОМО ЕUDAIMONICUS: РОЛЬ НОВОЇ АНТРОПОЛОГІЧНОЇ МОДЕЛІ У ПЕРЕФОРМАТУВАННІ СУЧАСНОЇ СИСТЕМИ ОСВІТИ}

Розглянуто особливості нової антропологічної моделі homo eudaimonicus, a також специфіку та перспективи їі впровадження у сучасній системі освіти. Висвітлено ефективність моделі homo eudaimonicus для досягнення людиною тривалого та стійкого щастя, підвищення рівня задоволеності життям та покращення екологічної поведінки. Пояснено, що мета щастяорієнтованої освіти навчати дітей досягати щастя від суспільно корисних видів діяльності. Запропоновано методики для опанування дитиною часового континууму щастя, тобто вміння відчувати щастя від свого минулого, у теперішньому та завдяки створенню позитивних сценаріїв свого майбутнього (вміння планувати майбутнє).

Ключові слова: homo eudaimonicus, щастя, щастяорієнтована освіта, соціальне підприємництво, екологічна свідомість. 
Contemporary education system is facing new challenges and requirements. For making children competitive in their future and to prepare them for solving future problems that are going to become more and more complex than those we deal with today, the contemporary education must be reoriented for new goals and its content, values and strategy must be revised and redefined. Jack Ma, co-founder of Alibaba Group, emphasizes: "If we do not change the way we teach, further years later will be in trouble... We cannot teach our kids to compete with machines... We have to teach them something unique that machines can never catch up with... value, believing, independent thinking, teamwork, care for others..." [1].

Those new values, beliefs and models of cooperation are to be found in a newly emerging anthropological model - homo eudaimonicus. This model reflects the success of a contemporary person in overcoming the value crisis caused by the decline of the religious values in 19th and 20th century triggered in its turn by secularization. Homo eudaimonicus represents a new model of and behavior in the world as well as a new way to achieve happiness.

The current Western model of happiness pursuit that was shaped by philosophy of Modernity and has been propagated by Mass Culture occurs to be ineffective for a person and damaging for society. Homo economicus model - within the framework of which a person is seeking hedonic happiness and because of that is focused exclusively on her own needs and on maximization of her own profit in order to afford herself as many pleasures as possible - does not meet the requirements of the sustainable development and does not give a person a chance in the future. To survive and, moreover, to be happy, a person should reconsider her priorities and moral responsibilities.

According to a definition by Brundtland Commision [2, p. 54], "sustainable development is development that meets the needs of the present without compromising the ability of future generations to meet their own needs". In this regard, the Ukrainian philosopher and scientist Volodymyr Vernadskyi must be mentioned for his idea of the noosphere ethics implying new values and moral foundation of human behavior in the Age of scientific and technological advancement.

Homo eudaimonicus model is, indeed. an effective way for a contemporary person to deal with not only existential but also economic, social and ecological crises. Homo eudaimonicus is not a theoretical construct detached from life, on the contrary that is a real model of behavior, a lifestyle that becomes theoretically analyzed due to its popularization in the Western culture. Homo eudaimonicus is a person who defines happiness not as pleasures but as eudaimonia - the good life, well-being and flourishing. That is a person who considers moral behavior as a foundation for her happiness: to be a good person in order to be happy [3, p. 28]. That is a person who searches the sense and meaning of her life here and now in this earthly life without reference to transcendent absolute values. That is a person who guides her behavior with intersubjective secular values (human dignity, human flourishing etc.).

Homo eudaimonicus achieves happiness by combining the Aristotelian good life with what Martin Seligman calls the meaningful life [4, p. 15-18]. The good life is a moral life aimed at self-knowledge and self-development through actualization of one's talents and aptitudes. That is the life that is, on the one hand, self-centered, and, on the other hand, aimed at happiness with others and engagement with others. The meaningful 
life implies the aim to the higher life purpose, however this purpose is secular and is to be accomplished in this earthly life. We call it "a dream bigger than life" [5], that is a mission that provides a person with meaning and inspires throughout life. One might not even be capable of reaching this goal - "dream bigger than life" - in one's own lifetime, but a sense of contributing to it, a sense of engagement with others for reaching it, a sense of being a part of a meaningful and socially useful project gives a person a sense of life and feeling of happiness.

Homo eudaimonicus might be characterized with the following features: moral behavioy, environmental awareness, socially useful activity, care for others and creating life project. Studies show [6, p. 172, 177] that the following attitudes, believes and activities do provide, indeed, a person with a lasting and sustainable happiness: being happy with one's life as a whole (not just feel joy, pleasure or contentment with a particular moment or during a particular period). Homo eudaimonicus lifestyle is related to the emergence of a new business model - social business that is aimed not at maximization of profit but at receiving a psychological reward from one's meaningful activity (solving current social, economic, health care issues) [7, p.115].

In this contemporary eudaimonic interpretation happiness is a skill to be learned; and it is a skill that children should be taught and that a contemporary education system must be aimed at teaching. Even if there is no appropriate level of happiness culture in a child's family, the school should introduce an alternative way to happiness - eudaimonic one. Teaching children to achieve happiness from socially useful activities should become the main task of a contemporary education system.

So how to help children in developing the skill of eudaimonic happiness at school? Methods and techniques must help a child tomaster the temporal continuum of happiness: past (to form happy memories) - present (be happy with others in the present, to appreciate the present moment and to share happy experience) - future (to create a positive scenario of one's future, to make a life project). In order to tech forming happy memories, it is important to discuss with pupils their happy experience and positive impressions from class common activities (celebration of important dates for the class, festive events, trips etc.), to prompt them to focus on and to recollect happy moments and to fix them in memory by creating a "Class Journal of Happy Memories" that each pupil can contribute to by adding pictures, stories etc. Teaching to be happy in the present implies different types of team work during which pupils should feel a sense of belonging, engagement, support and appreciation. Teaching to be happy from anticipating one's the future is to be accomplished through different kinds of project work when a pupil can use imagination and creativity, learn time management, feel dopamine-type of happiness from being curious, motivated and excited to accomplish a useful and interesting task, chose a purpose, build a plan and master courage and persistence in making small steps for a big goal.

Therefore, a contemporary system of education should become happinessoriented, since happiness is a skill mastering which opens for a child a horizon of experiences for a healthy, happy and effective life in adulthood.

\section{REFERENCES}

1. https://www.youtube.com/watch?v=rHt-5-RyrJk

2. World Commission on Environment and Development (1987). 
3. Haybron, D. (2016). The Philosophical Basis of Eudaimonic Psychology. In Vittersø J. (Eds.) Handbook of Eudaimonic Well-Being (pp. 27-54). Cham: Springer.

4. Hamilton Hamilton, C. (2011). The Freedom Paradox: Towards a Post-Secular Ethics. Crows Nest: Allen\&Unwin.

5. Пурій Р., Лущ У. (2019). Планування щасливого життя. Львів: Літопис.

6. Binder, M. (2019). Homo Economicus and Happiness: Towards More Sustainable Development. In Rojas M. (Eds.), The Economics of Happiness: How the Easterlin Paradox Transformed Our Understanding of Wellbeing and Progress (pp.171 191). Cham: Springer.

7. Hysa X., Suparaku S. (2020). From Happiness to Super Happiness: Not a Tradeoff Anymore. Happiness and Contemporary Society: Conference Proceedings Volume (Lviv, March, 20-21, 2020), 114-116. DOI: https://doi.org/10.31108/7.2020.26 